\title{
PEMANFAATAN LIMBAH KERTAS SEBAGAI IMUN EKONOMI DI ERA PANDEMI KECAMATAN KANIGARAN KOTA PROBOLINGGO
}

\author{
THE USE OF WASTE PAPER AS IMMUNE ECONOMIC \\ IN THE ERA OF PANDEMICS KANIGARAN SUB DISTRICT \\ PROBOLINGGO CITY
}

\author{
Djoko Wahyudi $^{1)}$, Alief Muhammad ${ }^{2)}$, Dani Hari Tunggal ${ }^{3)}$, Hermanto ${ }^{4)}$ \\ ${ }^{1,2,3}$ Fakultas Teknik, Universitas Panca Marga \\ ${ }^{4}$ Fakultas Ekonomi, Universitas Panca Marga \\ ${ }^{1}$ Email: djokowahyudi@gmail.com
}

\begin{abstract}
Abstrak: Sampah diartikan sebagai material sisa yang tidak diinginkan setelah berakhirnya suatu proses yang cenderung merusak lingkungan di sekitarnya. Sampah dapat membawa dampak yang buruk pada kondisi kesehatan manusia. Sampah kertas merupakan sampah yang dapat dikelola lagi menjadi berbagai bentuk inovasi kerajinan tangan. Hasil pemilahan sampah kertas memiliki potensi untuk menghasilkan nilai tambah secara ekonomi yang lebih baik. Tim pengabdian masyarakat Universitas Panca Marga berupaya meningkatkan kerajinan tangan dari limbah kertas dengan melakukan pelatihan pemanfaatan limbah kertas. Hasil yang diperoleh dari kegiatan ini peserta dapat menambah pengetahuan tentang peningkatan ketrampilan dan kerajinan yang bernilai jual tinggi yang berbasis lingkungan.
\end{abstract}

Kata Kunci: Sampah kertas, kerajinan tangan, ekonomi

Abstract: The waste material interpreted as unwanted following the end of a process that tend to deform the environment. Garbage can be caused a bad in human health conditions. Paper waste constituting litter that can be administered to various forms of innovation handicrafts. The garbage sorting paper have the potential to add value to produce better economically. The university team devotion panca marga improving handicrafts from waste paper by doing training the use of waste paper. The results of this activity participants can increase knowledge and skills on the improvement craft are based high selling environment.

Keywords: Paper waste, handicrafts, the economy

\section{PENDAHULUAN}

Sampah secara umum dibagi menjadi dua jenis, yaitu sampah organik dan sampah anorganik. Sampah merupakan barang yang dianggap tidak berguna lagi yang berasal dari hasil kegiatan manusia berupa bahan organik maupun anorganik yang dapat terurai maupun yang tak dapat terurai yang berada di lingkungan kita. Pengelolaan sampah di masyarakat perlu dilakukan dengan tujuan agar kesehatan masyarakat semakin meningkat, kualitas lingkungan semakin baik, serta mengubah sampah menjadi sumber daya terutama meningkatkan pendapatan di 
era tatanan kehidupan baru. Pengelolaan sampah dianggap baik menurut sudut pandang kesehatan lingkungan jika sampah tidak menjadi tempat berkembang biak berbagai bibit penyakit dan tidak menjadi media penyebarluasan virus. Selain itu, sampah dapat dikatakan terkelola dengan baik, jika tidak mencemari udara, air, dan tanah serta tidak menimbulkan bau, tidak mengganggu nilai estetis, dan tidak menyebabkan kebakaran (Harimurti et al., 2020).

Sampah kertas memiliki potensi untuk menghasilkan nilai tambah ekonomi yang lebih baik, jika dikembangkan sebagai bahan baku untuk menghasilkan produk kreatif (Djunaidi, 2018).

Dampak pandemi Covid-19 ini sangat berdampak secara ekonomi bagi ibuibu PKK Kecamatan Kanigaran. Banyak kepala keluarga yang harus dirumahkan sementara atau yang terpaksa harus menerima untuk diberhentikan dari pekerjaannya. Hal ini tentunya berpengaruh dengan keuangan keluarga terhambat bahkan tidak sedikit yang keuangannya harus terhenti. Upaya untuk mengatasi dampak pandemi Covid-19 terhadap kondisi keuangan keluarga, maka perlu adanya upaya untuk penambahan penghasilan keluarga, salah satunya melalui kegiatan yang produktif dengan berwirausaha (Ratnaning, 2020) (M \& M, n.d.).

Oleh karena itu sebagai salah satu bentuk implementasi dari Tridarma Perguruan Tinggi, tim pengabdian masyarakat Universitas Panca Marga melakukan kegiatan pengabdian masyarakat berupa pelatihan inovasi kreatif kerajinan tangan dari limbah kertas. Kegiatan ini diharapkan bisa memberikan dorongan dan motivasi untuk dapat memulai berwirausaha dengan ketrampilan yang dimilikinya (Rais et al., 2019). Pelatihan pengelolaan sampah kertas ini diharapkan mampu membantu pemerintah dalam menangani sampah dam meningkatkan ekonomi masyarakat khusus ibu-ibu PKK Kecamatan Kanigaran Kota Probolinggo.

\section{METODE}

Metode yang digunakan dalam kegiatan pengabdian ini yaitu berupa pelatihan yang melibatkan partisipasi dari masyarakat Kelurahan Kanigaran khususnya ibu-ibu PKK di Kelurahan Kanigaran Kecamatan Kanigaran tentang peningkatan produktivitas melalui pelatihan kerajinan tangan pemanfaatan limbah kertas di era pandemi. Rangkaian kegiatan pengabdian masyarakat yang dilakukan 
oleh tim pengabdian masyarakat Universitas Panca Marga antara lain terdiri dari tahap perencanaan dan tahap pelaksanaan.

Pada tahap perencanaan, tim pengabdian masyarakat Universitas Panca Marga melakukan beberapa tahapan kegiatan. Tahap pertama, tim pengabdian masyarakat Universitas Panca Marga melakukan koordinasi pada tanggal 27 Januari 2021 di kantor Kecamatan Kanigaran dengan Bapak Camat Kecamatan Kanigaran dan Bapak Lurah Kanigaran terkait rencana kegiatan yang akan dilakukan diwilayah Kanigaran. Tahap Kedua, tim pengabdian masyarakat Universitas Panca Marga melakukan koordinasi dengan pengurus PKK Kanigaran pada tanggal 03 Februari 2021 dengan merencanakan kegiatan pelatihan yang akan dilakukan. Tahap ketiga, menentukan tempat pelaksanaan kegiatan pelatihan. Dan tahap keempat, menyiapkan materi yang akan disampaikan untuk memberi pengetahuan secara teknis pemanfaatan limbah kertas koran menjadi bentuk inovasi kerajinan tangan.

Tahap Pelaksanaan, tim pengabdian masyarakat Universitas Panca Marga bersama ibu-ibu PKK Kecamatan Kanigaran melakukan kegiatan pelatihan ini di salah satu rumah warga di Jl.Slamet Riyadi Gg Blimbing RT. 03 RW. 05 Kecamatan Kanigaran. Kegiatan pelatihan ini bertujuan untuk meningkatkan produktifitas ibu-ibu PKK melalui kerajinan tangan di era pandemi. Teknis pelaksanaan dengan metode penjelasan atau uraian, tanya jawab dan pembuatan kerajinan tangan dari limbah kertas.

\section{HASIL DAN PEMBAHASAN}

Kegiatan pengabdian masyarakat ini dilaksanakan pada hari Rabu tanggal 10 Februari 2021. Pelaksanaan pengabdian masyarakat oleh tim pengabdian masyarakat Universitas Panca Marga berlangsung dengan lancar dan antusias dari ibu-ibu PKK Kelurahan Kanigaran cukup tinggi. Kegiatan pelatihan ini diawali dengan penyampaian materi atau arahan dari beberapa narasumber terkait pentingnya berwirausaha apalagi diera pandemi ini. Diawal kegiatan bisa diketahui beberapa peserta ada yang paham dan beberapa yang belum paham bagaimana cara berwirausaha di era pandemi saat ini. Dengan beberapa uraian dari narasumber tim pengabdian masyarakat Universitas Panca Marga akhirnya pemahaman berwirausaha dapat dimengerti. Karena dengan berwirausaha ibu-ibu 
PKK bisa memanfaatkan waktu luang untuk melakukan kegiatan yang produktif menjadi meningkat.

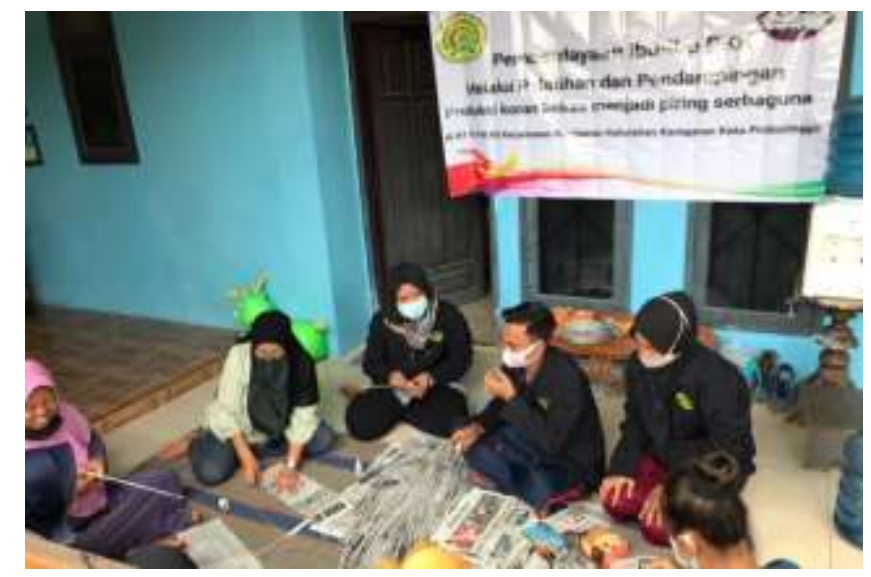

Gambar 1. Penyampaian awal kegiatan kerajinan tangan

Pada gambar 1, tim pengabdian masyarakat Universitas Panca Marga memberikan penjelasan rencana kegiatan yang akan dilakukan. Dalam hal ini adalah persiapan alat dan bahan yang diperlukan dalam kerajinan tangan limbah kertas koran.

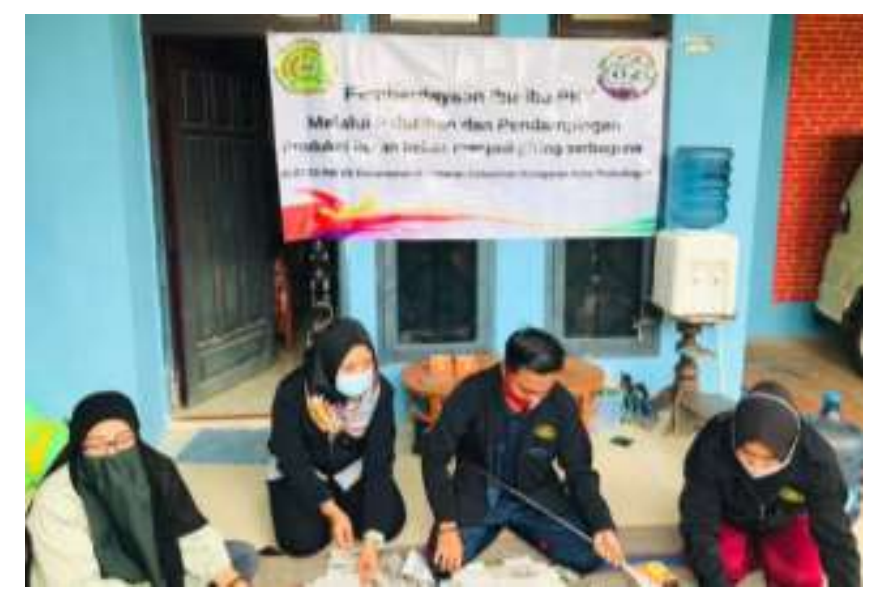

Gambar 2. Mendemonstrasikan kerajinan tangan

Gambar 2 menunjukkan tim pengabdian masyarakat melakukan demonstrasi pembuatan kerajinan tangan dari kertas koran yang diikuti ibu-ibu PKK. 


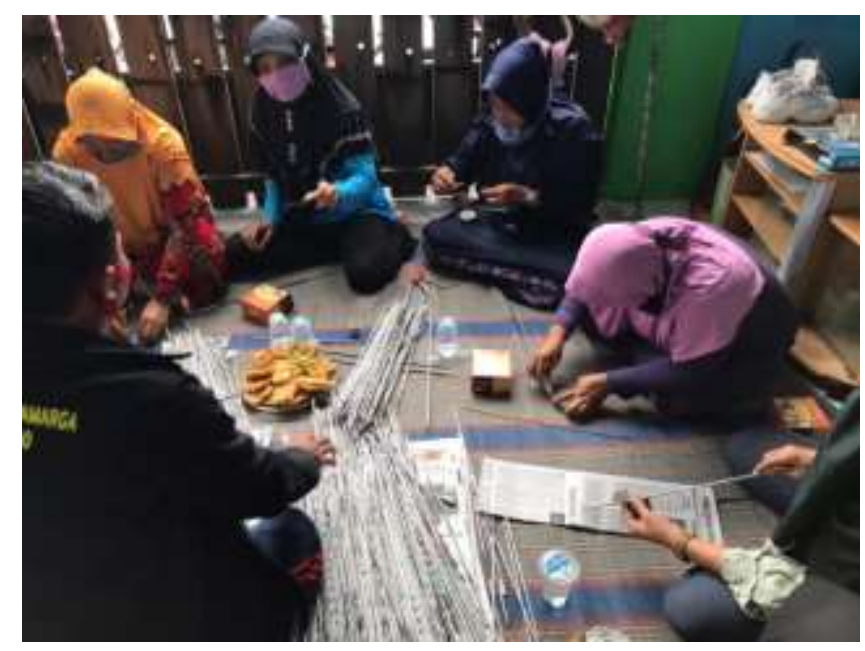

Gambar 3. Ibu-ibu PKK mempraktekan kerajinan tangan

Gambar 3 menunjukkan antusias dari ibu-ibu PKK dalam mengikuti pelatihan pembuatan kerajinan tangan yaitu proses pelipatan kertas koran dari kertas koran berukuran besar kemudian dipotong menjadi 4 bagian. Kemudian bagian yang sudah terpotong dilipat kecil dari ujung koran hingga berbentuk panjang, dan seterusnya untuk bagian-bagian selanjutnya. Pelipatan diperlukan kertas koran sesuai kebutuhan dari bentuk kerajian tangan yang akan dibuat.

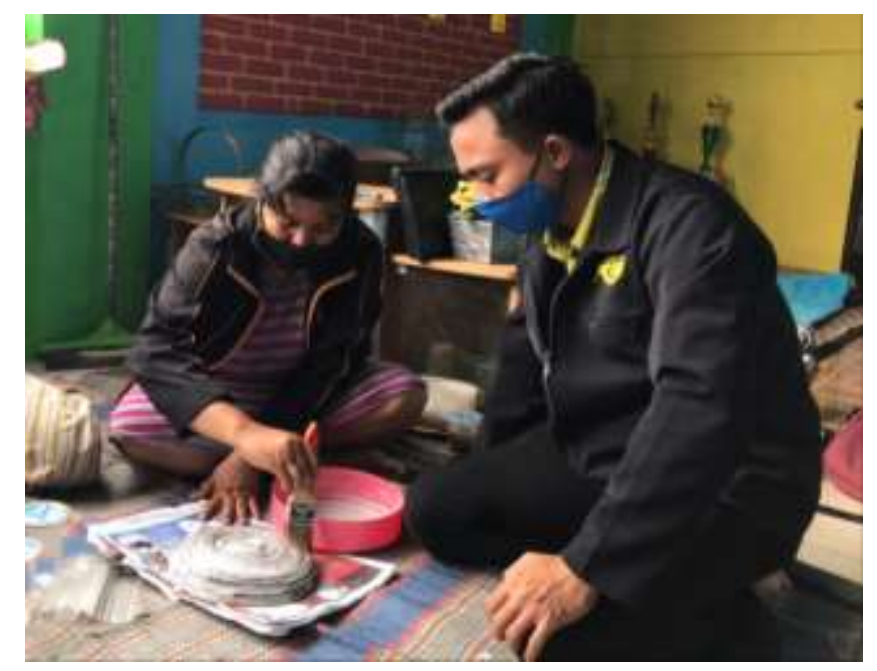

Gambar 4. Tim pengabdian memberikan arahan pembuatan motif kerajinan tangan 


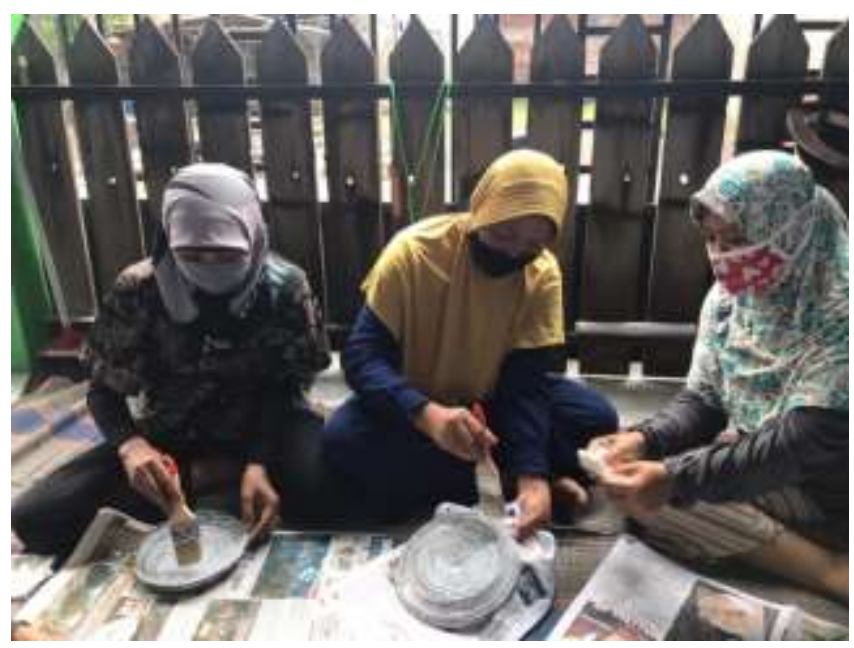

Gambar 5. Ibu-ibu PKK mempraktekan pembuatan motif kerajinan tangan

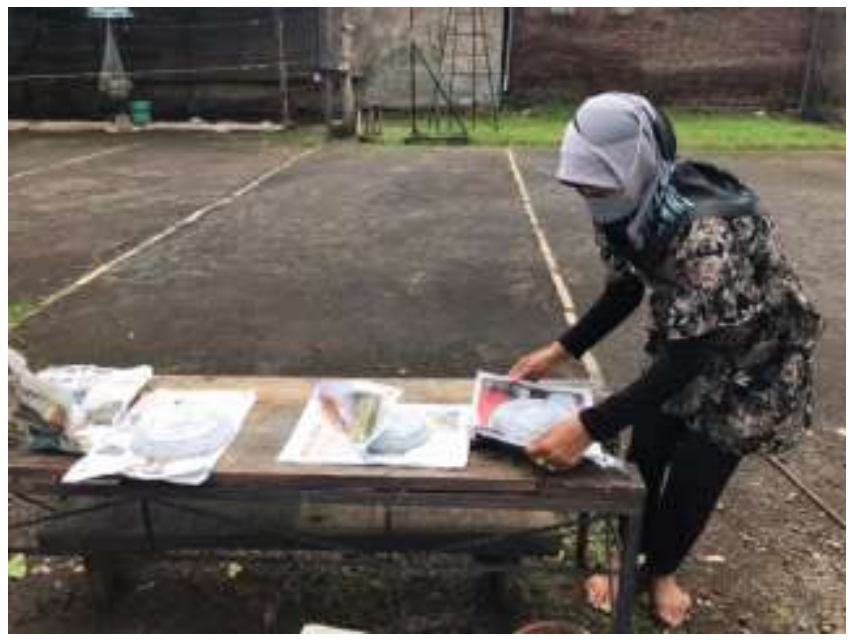

Gambar 6. Proses pengeringan

Gambar 4 sampai dengan gambar 6 merupakan proses membuat motif kerajian tangan dalam bentuk piring sesuai arahan salah satu tim pengabdian masyarakat dari Universitas Panca Marga. Pembuatan motif piring yang sekaligus di beri lem supaya motif yang dibuat tidak berubah. Kemudian dilakukan pengeringan lem untuk penyelesaikan tahap selanjutnya yaitu pemberian warna atau pengecatan sesuai selera atau pemesanan warna dari konsumen. 


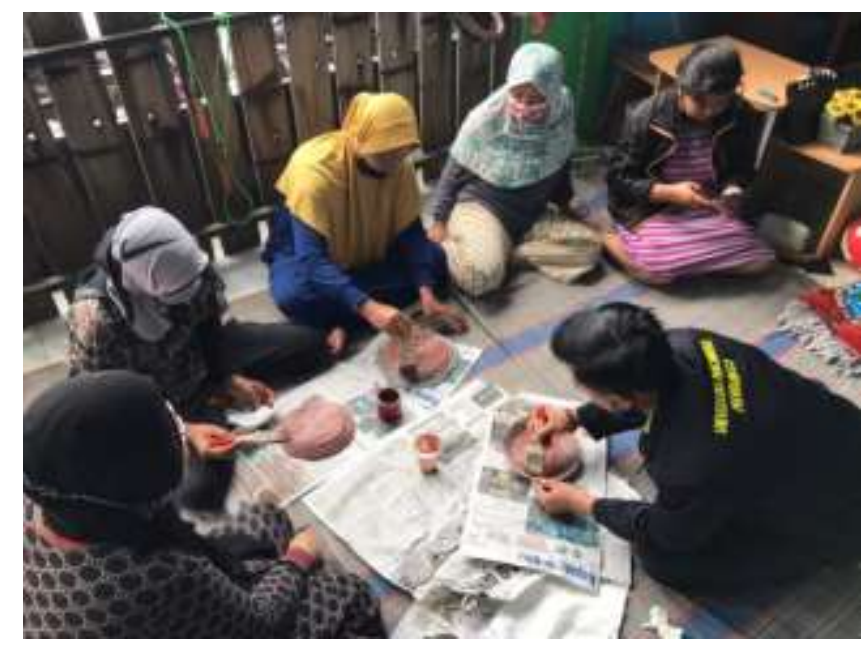

Gambar 7. Proses pengecatan kerajinan tangan oleh ibu-ibu PKK

Gambar 7 menunjukkan ibu-ibu PKK melakukan proses pengecatan atau pemberian warna pada piring dari kertas koran. Hal ini menunjukkan bahwasannya tahap demi tahap ibu-ibu PKK sudah bisa mempraktekan pembuatan kerajinan tangan sesuai arahan dari tim pengabdian masyarakat Universitas Panca Marga.

Dari rangkaian kegiatan pengabdian masyarakat yang dilakukan oleh tim pengabdian dari Universitas Panca Marga mulai dari koordinasi rencana pelaksanaan hingga pelaksanaan pelatihan, ada beberapa hal yang bisa diperoleh dari pelatihan diantaranya adalah

1. Menambah wawasan atau pengetahuan berwirausaha.

2. Menambah pengalaman dalam bidang kerajinan tangan khususnya pemanfaatan limbah kertas koran.

3. Memanfaatkan waktu luang melalui kegiatan yang produktif.

4. Hasil kerajinan tangan bisa dipasarkan dengan harga terjangkau untuk menambah penghasilan dengan memanfaatkan media sosial.

Dengan alat dan bahan yang mudah didapat, ibu-ibu PKK Kecamatan Kanigaran diharapkan bisa mengembangkan hasil pelatihan ini. Dorongan dan motivasi juga diberikan oleh tim pengabdian masyarakat Universitas Panca Marga kepada peserta pelatihan sehingga diera pandemi ini ibu-ibu tetap bersemangat bisa memanfaatkan waktu luang dengan kegiatan yang produktif melalui berwirausaha. Tim pengabdian masyarakat Universitas Panca Marga berharap 
bahwasannya hasil pelatihan pembuatan kerajinan tangan dari limbah kertas koran bisa menambah perekonomian ibu-ibu PKK diera pandemi ini.

\section{KESIMPULAN}

Kegiatan pengabdian masyarakat Universitas Panca Marga dilakukan selama bulan Januari hingga Februari yaitu koordinasi tanggal 27 Januari 2021 dan 03 Februari 2021, pelaksanaan pelatihan pada hari Rabu tanggal 10 Februari 2021 di Jl.Slamet Riyadi Gg Blimbing RT. 03 RW. 05 Kecamatan Kanigaran. Konsep yang diberikan adalah berupa pelatihan secara teknis dan pendampingan selama pelatihan pemanfaatan limbah kertas koran menjadi kerajinan tangan yang penuh inovatif.

Kegiatan pengabdian pelatihan pemanfaatan limbah kertas koran ini mendapat dukungan dan antusias dari ibu-ibu PKK sehingga kegiatan dapat menambah wawasan atau pengetahuan berwirausaha, dapat menambah pengalaman dalam bidang kerajinan tangan khususnya pemanfaatan limbah kertas koran, dapat memanfaatkan waktu luang melalui kegiatan yang produktif. Sehingga hasil kerajinan tangan bisa dipasarkan dengan harga terjangkau untuk menambah penghasilan baik dengan memanfaatkan media sosial atau dipasarkan melalui pasar tradisional.

\section{UCAPAN TERIMA KASIH}

Kami mengucapkan terima kasih kepada pihak-pihak yang berkontribusi dalam kegiatan pengabdian masyarakat dapat berjalan dengan lancar yaitu:

1. Prof. Dr. Ir. H. R. Abdul Haris, M.M selaku Rektor Universitas Panca Marga Probolinggo.

2. Hermanto, SE, MM selaku Ketua Lembaga Penelitian dan Pengabdian Masyarakat (LPPM) Universitas Panca Marga.

3. Agus Rianto, S.STP., M.Si. selaku Kepala Camat Kecamatan Kanigaran Kota Probolinggo.

4. Segenap RT dan RW Kelurahan Kanigaran, Kecamatan Kanigaran Kota probolinggo.

5. Segenap Masyarakat yang berada di Kelurahan Kanigaran Kecamatan Kanigaran Kota Probolinggo.

6. Rekan-rekan dosen dan mahasiswa di lingkungan Universitas Panca Marga. 


\section{DAFTAR PUSTAKA}

Djunaidi, M. (2018). Pelatihan Pengolahan Limbah Kertas. 1(2), 53-58.

Harimurti, S. M., Rahayu, E. D., Yuriandala, Y., Koeswandana, N. A., Sugiyanto, R. A. L., Perdana, M. P. G. P., Sari, A. W., Putri, N. A., Putri, L. T., \& Sari, C. G. (2020). Pengolahan Sampah Anorganik: Pengabdian Masyarakat Mahasiswa pada Era Tatanan Kehidupan Baru. Prosiding Konferensi Nasional Pengabdian Kepada Masyarakat Dan Corporate Social Responsibility (PKM-CSR), 3, 565-572. https://doi.org/10.37695/pkmcsr.v3i0.883

M, O. N. T., \& M, B. A. (n.d.). Pemanfaatan limbah kertas dengan menggunakan teknik.

Rais, M., Razak, R., \& Rappang, U. M. (2019). Pemanfaatan Koran Bekas pada Kerajinan Tangan Masyarakat Sipodeceng Profesional, Islami. March, $1-36$.

Ratnaning. (2020). Pengabdian Integritas : Jurnal Pengabdian, 4(1), 1-12. 